\title{
LAND REFORM AND SUSTAINABLE DEVELOPMENT - A SOUTH AFRICAN PERSPECTIVE
}

\section{Muswaka}

Vaal University of Technology

Email: indam2@vut.ac.za

Orcid: 0000-0001-4412-0356

\section{-Abstract-}

Land reform entails initiatives embodied in legislative, policy and other measures, constituting actions and mechanisms aimed at broadening access to land, improving security of tenure and restoring land or rights in land, all of which have become necessary because of the historical racial and inequitable approach to land in South Africa. Land reform therefore, consists of three main pillars, namely restitution of land rights, redistribution of land rights and improving security of a wide range of tenure forms. The focus of this paper is primarily on land tenure reform as an important element of land reform. The emphasis is on the legal arrangements used in South Africa to effect land tenure reform. The aim is to investigate the adequacy, flaws, challenges and effectiveness of the legal arrangements used in South Africa to effect land tenure reform. The qualitative method of research will be employed in this study. The reason is that it is best suited to this type of study which entails a critical analysis of legal issues. The study inter alia makes the finding that if land reform is pursued merely on the basis of political ideology and expediency, the economic and social costs will soon outstrip the perceived benefits of radical land acquisition. At the same time, it must however, be recognised that the majority have reasonable expectations for land holding patterns to change in order to address historical imbalances. The researcher concludes by submitting that property can no longer be seen, as it was defined in the common-law tradition, an island of sovereignty where the individual can do whatever she likes. Caution should be taken, therefore, in seeing property rights as the means by which to best secure tenure rights. Rather, security of tenure grounded in the human rights framework should be clearly articulated and properly seen as a fundamental human right.

Keywords: Land reform, Land tenure, constitution, property rights JEL Code: K11

\section{Cite (APA)}

Muswaka, L . (2019). Land Reform and Sustainable Development - A South African Perspective. International Journal of eBusiness and eGovernment Studies, 11 (1), 34-52. Doi: 10.34111/ ijebeg.20191113 


\section{INTRODUCTION}

Land reform entails initiatives embodied in legislative, policy and other measures, constituting actions and mechanisms aimed at broadening access to land, improving security of tenure and restoring land or rights in land, all of which have become necessary because of the historical racial and inequitable approach to land in South Africa (McCusker, Moseley \& Ramutsindela, 2015). Land reform therefore, consists of three main pillars, namely restitution of land rights, redistribution of land rights and improving security of a wide range of tenure forms (van der Walt \& Pienaar, 2012). Restitution of land rights is a process that is aimed at restitution of specific lands that were taken away from specific people during the apartheid era (Badenhost, Pienaar \& Mostert, 2015). Redistribution of land rights involves various programmes and processes aimed at obtaining land and making it available quickly and cheaply, both in the urban and rural areas (van der Walt \& Pienaar, 2012). The upgrading of security of tenure involves legislation and other steps to improve the quality and the security of existing land rights, especially in cases where security of tenure was undermined or prevented by apartheid policy (van der Walt \& Pienaar, 2012). The focus of this paper is primarily on land tenure reform as an important element of land reform, although some comments will be made to land reform in general. It therefore falls beyond the scope of this study to compare and analyse different land reform policies in the broadest sense. The emphasis is rather on the legal arrangements used in South Africa to effect land tenure reform. It is not intended to provide a detailed overview of historical land practices and discriminatory policies in South Africa. Suffice to say that the effects of the apartheid land law on the black population were cruel and while land reform seeks to redress the injustices of the past and while it has indeed brought justice to some, it can never fully compensate the suffering caused through dispossession. It can only be a step towards healing and reconciliation (van der Walt \& Pienaar, 2012).

The aim of the paper is to investigate the adequacy, flaws, challenges and effectiveness of the legal arrangements used in South Africa to effect land tenure reform. As will be highlighted in this paper, this is important, primarily because land tenure security guarantees the existence of land rights, ensures protection of 
rights through legal remedies when those rights are challenged or abused and provides landowners and users with confidence that they will not be arbitrarily deprived of their rights over particular lands and resources. Furthermore, secure land tenure can improve livelihoods and sustainable management of natural resources, including forests and promote sustainable development and responsible investment that eradicates poverty and food insecurity. Against this backdrop, it will be argued that secure land tenure plays a critical role towards the realisation of Sustainable Development Goals and the Aspirations related to inter alia, poverty alleviation, food security, environmental sustainability and advancing women's empowerment worldwide. In this regard, reliance will be made on the Sustainable Development Goals as provided for in the United Nations document, Transforming Our World: The 2030 Agenda for Sustainable Development and the Aspirations as provided in the African Union document, Agenda 2063.

\section{BRIEF HISTORICAL BACKGROUND}

The land reform programme in South Africa exists against the background of inequality and injustice caused by decades of apartheid land law. Therefore, in order to get a more comprehensive overview of what land reform entails it is necessary to sketch the outlines of apartheid land law as it existed before 1991 . Four main statutes are important in this regard. First, is the Black Land Act 27 of 1913; with this Act, grand apartheid in the rural areas was established. Eight percent of the land was identified as 'traditionally black' and reserved for exclusive use and occupation by black groups, while all other land in the country was reserved for exclusive use and occupation by the whites. Secondly, is the Development and Trust Land Act 18 of 1936. This Act extended the reserved land by five percent with the addition of the so called 'released' land. All rural land which was 'reserved' for blacks in these two statutes (thirteen percent of the land in the country reserved for more than eighty percent of the population) was held either according to customary law or in terms of special land rights created by these laws. These rights rarely amounted to full ownership and large tracts of land were in fact owned by the state, which held them in trust for the tribal communities actually living in the land (van der Walt \& Pienaar, 2012). The physical effects of grand apartheid were cruel. The amount of land reserved was 
inadequate for the people living off it. The situation was exacerbated by the lack of opportunities for expansion and development as it became impossible for the growing number of people to survive on the land they had. The result was largescale poverty, overcrowding, overgrazing and lack of social services which eventually forced male family members to relocate to the urban areas, where job opportunities, especially in the mining industry, were available for unskilled labour.

The third statute is the Group Areas Act 36 of 1966 which set aside in the urban areas, special residential areas for the black, coloured and Indian groups as identified by the Population Registration Act 30 of 1950. The designation of land as a group area implied that only people belonging to that race group were allowed to own, occupy and use land in that area for any purpose. The temporary land rights which could be obtained in these urban townships were prescribed and controlled by regulations issued in terms of the Black Local Authorities Act 102 of 1982, the Black Communities Development Act 4 of 1984 and the Blacks (Urban Areas) Consolidation Act 25 of 1945 and held by permission from the white controlled townships administrations. These insecure land rights consisted of site permits, residential permits, lodgers' permits, certificates of occupation and hostel permits. All these forms of landholding were temporary and insecure. One of the most important results of the strict control over urbanisation and housing in group areas was the growth of squatter settlements or informal settlements. Despite strict controls, squatter communities increased enormously since the 1980s. These communities usually consisted of people who moved to the urban or peri-urban areas because of poverty, lack of opportunities and overcrowding in the rural areas. The fourth important stature is the Prevention of Illegal Squatting Act 52 of 1951. This was by far the most draconian of all apartheid land laws. The Act forced private landowners and public authorities to demolish and remove all buildings and structures erected without consent of the landowner or in contravention of planning provisions and building regulations.

Given the above background, it is without doubt that in the South African context, improving security of land tenure is critical. There is a pressing need to rectify the 
land situation created by apartheid and to establish a measure of normality and fairness as far as the land issue is concerned. An important aspect of the process through which greater normality and fairness regarding the land issue is promoted is land reform. However, if this process (of land reform) is pursued merely on the basis of political ideology and expediency, the social and economic costs will soon outstrip the perceived benefits of radical land acquisition. Notwithstanding this, the majority have reasonable expectations for land holding patterns to change in order to address historical imbalances. It is thus, crucial that the legal arrangements used in South Africa to effect land tenure reform are efficient and effectively implemented. In the following discussion, the legal framework relating to land reform in South Africa is discussed. The Constitutional framework presents the starting point as South Africa has a system of constitutional supremacy. Inherent in this term is the idea that the Constitution is the supreme law. Section 2 of the Constitution of the Republic of South Africa provides that that the constitution is the supreme law of the land and that any law or conduct inconsistent with it is invalid (Constitution, 1996).

\section{THE CONSTITUTIONAL FRAMEWORK}

Section 25 of the Constitution of the Republic of South Africa 1996 has entrenched the right to property as a fundamental right. The property clause is however, recognized as a 'two pronged' mechanism with which to protect private property against impermissible imposition on the one hand, and with which to bring about transformation of existing patterns of private property on the other. This shows that notwithstanding the constitutional imperative to protect private property, it was also vitally important for the Constitution to attempt to redress the imbalances of the past as a result of apartheid. In this regard, the courts are therefore required to play a dual role in balancing out the tensions and conflicting interests that arise between the protective and reformative characteristics of the constitutional right to property (Currie \& de Waal, 2013). 
The three pillars of land reform are constitutionally entrenched viz redistribution in terms of section 25(5) which places a duty on the State, within its available resources, to take steps to promote equitable access to land; tenure security reform in terms of section 25(6) which provides that those people whose land rights are insecure because of past discriminatory laws or practices are entitled to security of tenure as provided by law, or to comparable redress; and redistribution in terms of section 25(7) which provides the basis for restitution of land rights. Section 25(4) is important as it deals with the interpretation of two important aspects. Firstly, section 25(4)(a) states that the term 'public interest,' which is a justification for expropriation in terms of section 25(2), must be interpreted to include the nation's commitment to land reform. Secondly, in terms of section 25(4)(b), reference to property that may be expropriated is not limited to land. Section 39(1) of the Constitution which requires that the interpretation of the Bill of Rights must consider international law is also relevant in the interpretation of the property clause. Section 25(8) ensures that any state action aimed at land, water and similar reforms aimed at redressing past inequalities, will be justified in terms of section 25 as long as these measures conform with section 36. Section 25(9) places a duty on parliament to enact security of tenure legislation foreseen in section 25(6).

This paper mainly focuses on land tenure reform, hence section 25(6) of the Constitution forms the foundation on which the main discussion unfolds. It is noteworthy that an infringement of section 25(6) of the Constitution through ineffective implementation and enforcement of legislation pertaining to land tenure reform automatically violates various other human rights entrenched in the Constitution such as the right to have access to adequate housing, rights to culture and to sufficient food. These rights are also guaranteed in the International Covenant on Economic, Social and Cultural Rights, (United Nations, 1966a) and the International Covenant for Civil and Political Rights, (United Nations, 1966b) both of which South Africa has ratified. South Africa, thus, also has an international obligation to prevent situations within its jurisdiction that may violate these rights hence the steps undertaken to promote land tenure reform.

\section{TENURE REFORM - THE LEGISLATIVE FRAMEWORK}


Tenure reforms involves legislation and other steps aimed at improving the quality and security of existing land rights, especially in cases where security of tenure was undermined or prevented by the apartheid policy. As has been highlighted, this aspect of land reform is authorised by section 25(6) of the Constitution, which provides that a person or community whose tenure of land is insecure because of past racially discriminatory laws or practice is entitled to secure tenure or other redress as provided for in a law of parliament. The main purpose is to make existing land rights more secure by protecting the holders of those rights against unfair evictions. Section 26(3) of the Constitution also plays an important role in this regard as it provides protection against eviction. The section provides that no one may be evicted from their home or have their home demolished without a court order, which may not be granted without taking into account all relevant circumstances. In light of the constitutional obligation placed on Parliament in terms of section 25(9), Parliament has enacted numerous legislation aimed at ensuring tenure reform. In the following discussion, selected legislation enacted to give effect to section 25(6) of the Constitution are discussed.

\subsection{The Land Reform (Labour Tenants) Act 3 of 1996}

Issues surrounding labour tenancy in South Africa are controversial and complex in that they reflect a struggle over access to land and tenure security that spans more than a century. In many instances, the labour tenants have enjoyed much longer relationships with the land they occupy than the farmer who legally owns the land. In many cases the land was expropriated from the African families who occupied it since time immemorial with the effect that they were reduced from the status of customary land owners to mere occupiers. They were thus forced to comprehend how a piece of paper in the form of a title deed lodged in some distant place could deprive them of the land that they were born on and where their ancestors were buried. The only place that they could call home now belonged to someone else and they lacked security of tenure in respect of that land. The Land Reform (Labour Tenants) Act was therefore enacted to address 
this issue. The Act regulates the special position of labour tenants, who have special right to the agricultural land that they occupy. Section 1 of the Act provides that a labour tenant means a person (i) who is residing or has the right to reside on a farm; (ii) who has or has had the right to use cropping, or grazing land on the farm of the owner and (iii) whose parent or grandparent resided or resides on a farm and had the use of cropping or grazing land on the farm of the owner, including a person who has been appointed a successor to a labour tenant but excluding a farm worker. In Zulu and Others $v$ Van Rensburg and Others, the land claims court decided that a person has to satisfy all three requirements in section 1 of the Act to qualify as a labour tenant. This was confirmed in Ngcobo and Others $v$ Van Rensburg. For purposes of tenure reform, the most important function of the Act is to protect labour tenants against unfair or unlawful evictions. Section 5 of the Act which is headed "Prohibition on Evictions" expressly stipulates that a labour tenant may only be evicted in terms of an order of court issued under the Act. In terms of section 6, no person other than the owner may institute proceedings for the eviction of labour tenant. An order for eviction will only be granted where the court deems it just and equitable. Section 14 prohibits the eviction of a labour tenant if an application of land in terms of chapter 3 of the Act is pending. This means that once a labour tenant has made such an application in terms of section 16 of the Act, he or she cannot be evicted pending the finalisation of such claim. It is submitted that effective implementation of the Act will offer labour tenants protection from arbitrary eviction and this, is the cornerstone of secure tenure.

\subsection{The Extension of Security of Tenure Act 62 of 1997}

The Extension of Security of Tenure Act (ESTA) is another Act of Parliament envisaged in section 25(6) of the Constitution to improve security of tenure for those 'whose tenure of land is legally insecure as a result of past racially discriminatory laws or practices.' The ESTA recognises that many South Africans do not have secure tenure of their homes and the land which they use and are therefore vulnerable to unfair eviction. It therefore, addresses the tenure rights of occupiers (excluding labour tenants) residing on land outside the urban areas with the permission of the landowner. In section 1(1)(x) of the ESTA, an occupier as 
defined as a person residing on land which belongs to another person and who has on or before 4 February 1997 or thereafter, had consent or another right in law to do so but excluding (a) labour tenants in terms of the Land Reform (Labour Tenants) Act; (b) a person suing or intending to use the land in question mainly for industrial, mining, commercial or commercial farming purposes; and (iii) a person who has an income in excess of the prescribed amount. In Venter $N O v$ Claasen it was held that ESTA does not apply to spouses of occupiers separately. A spouse acquired his or her right of occupation from a marriage relationship with another occupier, and not as an independent right of occupation, unless such right was based on an independent agreement with the owner. Protection of occupiers' rights follow in terms of the Act in two stages. Firstly, the permission to occupy the land may be revoked only according to the procedures laid down in the ESTA. Secondly, once the occupation has been revoked, the occupier can be evicted only according to procedures provided in the ESTA.

\subsection{The Prevention of Illegal Eviction from Unlawful Occupation of Land Act 19 of 1998}

The Prevention of Illegal Eviction from Unlawful Occupation of Land Act (PIE Act) unlike the Land Reform (Labour Tenant Act) and the ESTA applies to people who occupy land unlawfully. The PIE Act provides strict requirements and procedures for the eviction of these occupiers as some of them would have occupied the land for a very long time and in some instances, the reason for the occupation is sometimes a technicality. The PIE Act also contains provisions to prevent further unlawful occupation of land. In the case of City of Cape Town $v$ Rudolf and Others, it was decided that the common la remedies like the spoliation remedy could not find application together with the PIE Act. In other words, if the PIE Act applies, the common-law remedies are disqualified, and the landowner cannot choose rather to make use of the common-law remedies. In Modder East Squatters and Another $v$ Modderklip Boerdery (Pty) Ltd the Supreme Court of Appeal reconciled the conflict of law between section 25 property rights and section 26 right to have access to adequate housing by ordering the State authorities to compensate the owner of the land for the costs associated with its occupation by the informal settlement until the State authorities could provide 
alternative land for the residents of that settlement. In the case of Port Elizabeth Municipality $v$ Various Occupiers, the court confirmed that the Constitution obliges the courts to find a reasonable and just balance between the rights of landowners and the interests of even unlawful occupiers. The court reasoned that while unlawful occupiers do not have any occupation rights according to the common law, their vulnerable position and human dignity must still be taken into account. Therefore, an order to evict them should not be given too easily and definitely not without taking all the circumstances into account. At the same time the court emphasised that eviction is not impossible and that even if eviction would render the occupiers homeless, the landowner's rights must also be protected and if it appears just and equitable in all the circumstances, an eviction order should be granted.

\section{SUSTAINABLE DEVELOPMENT GOALS}

In the effort to address global sustainability challenges affecting people, prosperity and planet, in September 2015, the United Nations member states adopted Transforming our World: The 2030 Agenda for Sustainable Development, (United Nations, 2015), which includes a set of Sustainable Development Goals for 2015-2030. The Agenda provides a successor framework for the Millennium Declaration and the Millennium Development Goals that covered the period from 2000-2015, (United Nations, 2000). The Sustainable Development Goals represent the world's comprehensive plan of action for social inclusion, environmental sustainability and economic development. In the same year, the African Union (AU) adopted Agenda 2063 as the continent's new long-term vision for the next 50 years. Both of these international guides require States to commit to inter alia land tenure security. In the following discussion, security of land tenure in relation to the Sustainable Development Goals as well as the Aspirations is discussed.

\subsection{Land Tenure and Sustainable Development Goals}


Land tenure reform as provided for in section 25(6) of the Constitution, coupled with good land governance is critical in accelerating the achievement of many Sustainable Development Goals. In the same light, infringement of section 25(6) of the Constitution poses significant challenges for advancing the Sustainable Development Goals. For instance, failure to afford a person or community whose tenure of land is legally insecure because of past racially discriminatory laws or practices, either tenure which is legally secure or comparable redress, hinders the achievement of the Sustainable Development Goal 1 and Sustainable Development Goal 2. Sustainable Development Goal 1 focuses on ending poverty in all its forms. This goal is aimed at ensuring that all men and women, in particular the poor and the vulnerable, have equal rights to economic resources, as well as access to basic services, ownership and control over land and other forms of property, inheritance, natural resources, appropriate modern technology and financial services, including micro-finance. Sustainable Development Goal 2 focuses on ending hunger, achieving food security and improved nutrition, and promoting sustainable agriculture. This goal is aimed at doubling the agricultural productivity and incomes of small-scale food producers, in particular women, indigenous peoples, family farmers, pastoralists and fishers, including through secure and equal access to land, other productive resources and inputs, knowledge, financial services, markets and opportunities for value addition and non-farm employment by 2030. The goal emphasises the importance of smallscale agricultural producers to feeding the world's poor and vulnerable.

It is argued that the continued existence of insecure tenure for, for example, labour tenants in terms of the Land Reform (Labour Tenants) Act and occupiers in terms of the ESTA, affects the security of their access to food and promotes poverty and hunger. There is therefore, need for considerable effort by the government to improve security of tenure of existing land rights by the poor and vulnerable for Sustainable Development Goal 1 and 2 to be achieved. In South Africa, effort in this regard is evidenced by the wide array of legislation on land tenure reform that exists. However, infringement of section 25(6) of the Constitution is still prevalent as tenure reform remains neglected and consequently, challenges towards meeting these goals still exists. Farm labour tenants and occupies continue to be vulnerable to eviction. Thousands of claims have been ignored, and 
only recent court action has forced the Department of Rural Development and Land Reform to recommit itself to resolving them. In the case of Mwelase and Others $v$ Director General for Department of Rural Development and Land Reform Others, the court, referring to the Department of Rural Development and Land Reform noted, "From the history of the litigation, it is apparent ... that the Department has not been able to comply with its own time frames or to provide accurate information on how far the collation of labour tenant's claims had progressed ... the Department has also not filed updated implementation plans ..." There is thus a wide gap between the legislative framework concerning land tenure reform and its implementation and/or enforcement. The gap needs to be closed if real progress is to be made on land tenure reform. Laws must therefore, be effectively implemented.

Sustainable Development Goal 5 focuses on achieving gender equality and empowering all women and girls. States are inter alia required to, "undertake reforms to give women equal rights to economic resources, as well as access to ownership and control over land and other forms of property ..." The distinction between the land rights of men and those of women is necessary as a safeguard to ensure that development agendas do not leave women behind, unintentionally exacerbating the gender asset gap and undermining governments' ability to meet Sustainable Development Goals' targets. It is submitted that the application of section 9(2) of the Land Reform (Labour Tenants Act) and section 8(5) of the ESTA frustrates the achievement of Sustainable Development Goal 5. The former section provides that on the death of a labour tenant who has retained the right to occupy the farm in terms of the provisions of subsection (1), all his or her associates may be given twelve calendar months' notice to leave the farm. Similarly, the latter section requires, upon the death of a male occupier, the spouses and dependents of the male occupier to vacate the farm upon the expiration of the twelve months period. It is argued that these provisions have the potential of leaving many women and children in extremely vulnerable positions, as they face the reality of homelessness after the expiration of the twelve-month period in the aftermath of the death of the male occupier as legislated or earlier if a breach occurs. It is recommended that the said provisions be repealed. Furthermore, provisions giving women secure land tenure in the event of the 
death of the male labour tenant or occupier should be inserted in the mentioned statutes.

In addition to the explicit land-related goals discussed above, a number of goals have implicit land-related outcomes. For instance, Sustainable Development Goal 10 which focuses on reducing inequality within and among countries has particular implications for reducing inequality of land access and protection of property rights from discriminatory policies and practices. Effective implementation of land tenure reform in South Africa will aid the achievement of this goal. Sustainable Development Goal 11 focuses on making cities and human settlements inclusive, safe, resilient and sustainable. It aims to address the chronic lack of property rights for informal urban settlements or slums across the developing world and the related rural conditions that drive mass, unplanned urban migration. In line with this goal, it is submitted that land reform in South Africa should also put focus on informal urban settlements. Land reform currently focuses mainly on rural areas but urbanisation and growth of informal settlements, some on communal land in peri-urban areas means that key needs and opportunities are missed. Sustainable Development Goal 15 focuses on life on land. It aims to protect, restore and promote the sustainable use of terrestrial ecosystems, sustainably manage forests, combat desertification, halt and reverse land degradation and halt biodiversity loss. This reflects the growing recognition of the importance of the role of improved security of tenure in fostering conservation and community stewardship of natural resources. Sustainable Development Goal 16 focuses on promoting peaceful and inclusive societies for sustainable development, providing access to justice for all and building effective, accountable, and inclusive institutions at all levels. This requires developing and strengthening institutions such as land administration agencies, courts, and legal aid services to effectively enforce land and property rights and ensure the poor and vulnerable have equal access to mechanisms for addressing violations of their land rights. Be that as it may, it is submitted that all of these are possible only when there is a land governance system that is accessible, equitable, resource efficient and sustainable. 
INTERNATIONAL JOURNAL OF eBUSINESS AND eGOVERNMENT STUDIES

Vol 11, No 1, 2019 ISSN: 2146-0744 (Online)

\section{LAND TENURE AND $A G E N D A 2063$}

In 2015, the African Union (AU) adopted Agenda 2063 as the continent's new long-term vision for the next 50 years, (African Union, 2015). A detailed discussion of Agenda 2063 is not undertaken in this paper suffice to briefly highlight the connection between land tenure reform and the achievement of some of its aspirations. Agenda 2063 contains seven aspirations for "the Africa we want." Of relevance to the issue of land tenure is Aspiration 1 focuses on a prosperous Africa based on inclusive growth and sustainable development. This aspiration will be achieved through the determination to inter alia eradicate poverty. In this regard, Aspiration 1 of Agenda 2063 therefore resonates with the Sustainable Development Goal 1. Effective implementation of land tenure reform will therefore, also promote the achievement of Aspiration 1. Aspiration 3 which focuses on an Africa of good governance, democracy, respect for human rights, justice and the rule of law; Aspiration 4 focusing on a peaceful and secure Africa; and Aspiration 6 which focuses on an Africa whose development is people-driven, relying on the potential of African people, especially its women and youth, and caring for children are also relevant to the issue of land tenure. It is submitted that in the same way that land tenure reform as provided for in section 25(6) of the Constitution, coupled with good land governance is critical to accelerating the achievement of many Sustainable Development Goals, it is also equally important in enhancing the achievement of the Agenda 2063 Aspirations and its related goals.

\section{FINDINGS}

The study inter alia makes the following findings. Firstly, that despite the legal framework relating to land tenure reform, the implementation of tenure reform laws has, to a large extent, been weak and ineffective has also been made. This is particularly the case with the Land Reform (Labour Tenants Act) and the ESTA. 
The case of Mwelase and Others $v$ Director General for Department of Rural Development and Land Reform Others, confirm that the developmental provisions to provide for secure long-term rights under these laws have largely not been implemented. It is recommended that land tenure reform legislation should be effectively implemented, especially in light of the crucial need to address land relations which were disturbed and skewed fundamentally during the apartheid era. Secondly, also made is the finding that land tenure reform is necessarily complex and time consuming. Therefore, State capacity, comprising strong leadership and management, adequate budgets, appropriate policies, sound institutional structures, efficient procedures as well as an effective system for monitoring and evaluation of land reform is crucial. Furthermore, it is also recommended that a Land Charter be developed to facilitate the implementation of a sustainable land reform. There is also a need to develop a Code of Practice or Principles to guide the relations between the Department of Rural Development and Land Reform and stakeholders. Thirdly, the study also makes the finding that effective implementation of land tenure reform in South Africa will yield the unintended positive result of accelerating the achievement of many Sustainable Development Goals as well as the Aspirations, goals and related targets of Agenda 2063. The recommendation in this regard is that land tenure reform must be effectively pursued as government endeavours to meet its obligations in terms of the Sustainable Development Goals and Agenda 2063. Fourthly, also made is the finding that an infringement of section 25(6) of the Constitution through ineffective implementation and enforcement of legislation pertaining to land tenure reform automatically violates various other human rights entrenched in the Constitution such as the right to adequate housing and the right to sufficient food. It also derails the achievement of Sustainable Development Goals such as Goal 11 focusing on making cities and human settlements inclusive, safe, resilient and sustainable and Goal 1 focusing on ending poverty. It is recommended that since South Africa furthermore has an international obligation to prevent situations within its jurisdiction that may violate these rights, effective steps to promote land tenure reform should be undertaken. Fifthly, a finding has also been made that the process of eviction as stipulated in the legislation pertaining to land tenure reform is far removed from the virtually automatic right of eviction that exists in terms of common law. In this regard, it is recommended that property can no longer be seen, as it was defined in the common-law tradition, an island of sovereignty where the individual can do whatever he/she likes. Caution should be taken 
therefore, in seeing property rights as the means by which to best secure tenure rights. Rather, security of tenure grounded in the human rights framework should be clearly articulated and properly seen as a fundamental human right.

\section{CONCLUSION}

Insecurity of land tenure is inter alia, a precipitating cause of poverty and inequality. It creates insecurity for landowners and land users that dampens investment, destroys livelihoods, foments conflict, creates unequal economic systems, locks assets in an unusable and untradeable form, discourages conservation, hampers sustainable domestic resource mobilization for increasing the availability of public services, and undermines principles of effective and democratic governance, (Mennen, 2016). However, secure land tenure can improve livelihoods and sustainable management of natural resources, including forests, and promote sustainable development and responsible investment that eradicates poverty and food insecurity. Improving the security of tenure of existing land rights goes hand in hand with the realisation of Sustainable Development Goals related to inter alia, poverty alleviation, food security, environmental sustainability and promoting gender equality through advancing women's empowerment. Land tenure security guarantees the existence of land rights, ensures protection of rights through legal remedies when those rights are challenged or abused, provides landowners and users with confidence that they will not be arbitrarily deprived of their rights over particular lands and resources, and creates land markets that unlocks its potential as an asset and encourages efficient allocation and transactions. In light of these innumerable benefits are to be reaped from land tenure reform, the researcher concludes by submitting that government should accelerate land tenure reform.

\section{REFERENCES}

Badenhost, P.J., Pienaar, J.M. \& Mostert H. (2015). Silberberg and Schoemans The Law of Property. LexisNexis: South Africa. 
INTERNATIONAL JOURNAL OF eBUSINESS AND eGOVERNMENT STUDIES

Vol 11, No 1, 2019 ISSN: 2146-0744 (Online)

Carey Miller, D.L \& Pope, A. (2000). Land Title in South Africa. Juta \& Co: South Africa.

Currie, I. \& de Waal J. (2013). Bill of Rights Handbook. Juta \& Co: South Africa.

McCusker, B., Moseley, W.G \& Ramutsindela, M. (2015). Land Reform in South Africa. United Kingdom.

Van der Walt, A.J. (2005). Constitutional Property Law. Juta \& Co: South Africa.

Van der Walt, A.J \& Pienaar, G.J. (2012). Introduction to the Law of Property. Juta \& Co: South Africa.

African Union (2015). Agenda 2063.

http://au.int/sites/default/files/pages/3657-file-

agenda2063 popular version en.pdf

United Nations (2015). Transforming Our World: The 2030 Agenda for Sustainable Development.

http://sustainabledevelopment.un.org/post2015/transformingourworld/publication

United Nations (1966a). International Covenant on Economic, Social and Cultural Rights.

http:// https://www.ohchr.org/Documents/ProfessionalInterest/cescr.pdf

United Nations (1966b). International Covenant for Civil and Political Rights.

http://www.ohchr.org/Documents/ProfessionalInterest/ccpr.pdf

United Nations (2000). Millenium Declaration.

http://www.un.org/millennium/declaration/ares552e.pdf

City of Cape Ton v Rudolf and Others 20045 SA 39 (C). 
INTERNATIONAL JOURNAL OF EBUSINESS AND EGOVERNMENT STUDIES

Vol 11, No 1, 2019 ISSN: 2146-0744 (Online)

Modder East Squatters and Another v Modderklip Boerdery 20043 All SA 169 (SCA).

Mwelase and Others v Director General for Department of Rural Development and Land Reform

\& Others 2017 (4) SA 422 (LCC).

Ngcobo and Others v Van Rensburg 19992 SCA 1057 (SCA).

Port Elizabeth Municipality v Various Occupiers 20051 SA 217 (CC).

Venter NO v Claasen en Andere 20011 SA 270 (LCC).

Zulu and Others v Van Rensburg and Others 19964 SA 1236 (LCC).

The Constitution of the Republic of South Africa, 1996.

The Black Communities Development Act 4 of 1984.

The Black Land Act 27 of 1913.

The Black Local Authorities Act 102 of 1982.

The Blacks (Urban Areas) Consolidation Act 25 of 1945.

The Development and Trust Land Act 18 of 1936.

The Extension of Security of Tenure Act 62 of 1997.

The Group Areas Act 36 of 1966.

The Land Reform (Labour Tenants) Act 3 of 1996.

The Population Registration Act 30 of 1950. 
INTERNATIONAL JOURNAL OF EBUSINESS AND EGOVERNMENT STUDIES

Vol 11, No 1, 2019 ISSN: 2146-0744 (Online)

The Prevention of Illegal Eviction from Unlawful Occupation of Land Act 19 of 1998.

The Prevention of Illegal Squatting Act 52 of 1951. 